\title{
PERBEDAAN LAMANYA PELEPASAN TALI PUSAT PADA BAYI DITINJAU DARI PERAWATAN DENGAN AIR SUSU IBU DAN PERAWATAN KASA KERING
}

Yuhemy Zurizah

Akademi Kebidanan Budi Mulia Palembang

\section{Informasi Artikel :}

Diterima : $\quad$ November 2018

Disetujui : $\quad$ Desember 2018

"Korespondensi Penulis :

Yuhemyz0@gmail.com

\begin{abstract}
A B S T R A K
Perawatan tali pusat yang benar dan lepasnya tali pusat dalam minggu pertama secara bermakna mengurangi insiden infeksi pada noenatus. Salah satu cara yang disarankan WHO dalam merawat tali pusat adalah dengan menggunakan pembalut kasa bersih yang sering diganti, selain itu sebagaimana juga disarankan penelitian diarahkan pada penggunaan anti septik dan zat-zat pengering tradisional misalnya ASI atau kolostrum. Tujuan penelitian ini adalah untuk mengetahui perbedaan lamanya pelepasan tali pusat pada bayi ditinjau dari perawatan dengan air susu ibu dan perawatan teknik kasa kering. Ruang lingkup penelitian ini ditujukan kepada lamanya pelepasan tali pusat pada bayi ditinjau dari perawatan dengan air susu ibu dan perawatan teknik kering terbuka dengan desain penelitian analitik comparative. Sampel pada penelitian ini 10 bayi dengan kasa kering dan 10 bayi dengan air susu ibu. Hasil yang diperoleh dari uji Independent Samples $t$ Test $p$ value $=0,018<0,05$ maka dapat dinyatakan ada perbedaan lamanya pelepasan tali pusat pada bayi ditinjau dari perawatan dengan air susu ibu dan perawatan teknik kasa kering. Disarankan kepada petugas kesehatan agar dapat mensosialisasikan perawatan tali pusat dengan air susu ibu yang dapat menyebabkan tali pusat lebih cepat lepas.
\end{abstract}

Kata Kunci : pelepasan Tali Pusat Pada Bayi, Air Susu Ibu, Kasa Kering

\begin{abstract}
Care of the umbilical cord completely and off the umbilical cord in the first week. One way that is used by WHO in the care of the rope is to use sanitary napkins that are often replaced, in addition to the use of antiseptic and traditional substances such as breast milk or colostrum. The purpose of this study was to find out the parts of treatment with breast milk and treatment of dry gauze techniques. The scope of this study is intended for treatment with milk and treatment techniques with comparative analytics. The sample in this study were 10 babies with dry gauze and 10 babies with breast milk. The results obtained from the Independent Samples $t$ Test $p$ value $=0.018<0.05$, it can be stated that there is a value of the length of the mop Talking the umbilical cord in infants in terms of treatment with breast milk and treatment of dry gauze techniques. So that you can socialize the care of the rope with breast milk which can cause the umbilical cord to loose more quickly.

Keywords $\quad$ :Release of Umbilical Cord in Babies, Mother's Milk, Dry Gauze
\end{abstract}

\section{PENDAHULUAN}

Perawatan tali pusat yang benar dan lepasnya tali pusat dalam minggu pertama secara bermakna mengurangi insiden infeksi pada noenatus. Infeksi merupakan salah satu penyebab kematian perinatal atau usia di bawah 1 bulan (Saifuddin, 2014).

Berdasarkan hasil sementara Survei Penduduk Antar Sensus (SUPAS) tahun 2015, Angka Kematian Bayi (AKB) di Indonesia 
mencapai 22 per 1000 kelahiran hidup (Kompas, 2016).

Data dari Dinas Kesehatan Provinsi Sumatera Selatan, jumlah kematian bayi pada tahun 2013 sebanyak 707 bayi, tahun 2014 terbanyak 626 bayi, dan tahun 2015 jumlah kematian neonatal sebanyak 558 bayi (Dinkes Provinsi Sumsel, 2016). Selanjutnya jumlah kematian bayi di Kota Palembang pada tahun 2013 sebanyak 168 bayi, tahun 2014 sebanyak 52 bayi, dan tahun 2015 jumlah kematian neonatal sebanyak 12 bayi (Dinkes Kota Palembang, 2016).

Penyebab kematian bayi di Kota Palembang antara lain adalah BBLR, down syndrome, infeksi neonatus, perdarahan intrakranial, sianosis, kelainan jantung, respiratory distress syndrome, post op hidrosefalus dan lainnya (Profil Seksi Pelayanan Kesehatan Dasar, 2015).

Nenurut Yefri dkk (2014), dilaporkan 460.000 bayi meninggal karena infeksi berat dengan infeksi tali pusat (omfalitis) sebagai salah satu predisposisi penting. Angka infeksi tali pusat di negara berkembang bervariasi dari 2 per 1000 hingga 54 per 1000 kehidupan dengan case fatality rate $0-15 \%$.

Upaya untuk mencegah infeksi tali pusat sesungguhnya merupakan tindakan sederhana, yang penting adalah tali pusat dan daerah sekitar tali pusat selalu bersih dan kering dan selalu mencuci tangan dengan air bersih dan menggunakan sabun sebelum merawat tali pusat (Sodikin, 2012).

Perawatan tali pusat kering dapat dilakukan sendiri oleh ibu si bayi di rumah sebagai upaya perawatan lanjutan. Perawatan yang tepat dan benar sangat menentukan cepat tidaknya tali pusat putus. Biasanya lama penyembuhan tali pusat dikatakan cepat jika kurang dari 5 hari. Penyembuhan normal jika antara $5-7$ hari dan lambat jika lebih dari 7 hari. Jika tali pusat belum juga pupus setelah 4 minggu atau adanya tandatanda infeksi seperti pangkal tali pusat dan daerah sekitarnya berwarna merah, keluar cairan yang berbau, ada darah yang keluar terus-menerus dan atau bayi demam tanpa sebab yang jelas, maka kondisi tersebut menandakan munculnya penyakit pada neonatus yang disebabkan oleh tali pusat (Putra, 2012).

Sudah banyak penelitian yang dilakukan untuk meneliti bahan yang digunakan untuk merawat tali pusat. Salah satu cara yang disarankan WHO dalam merawat tali pusat adalah dengan menggunakan pembalut kasa bersih yang sering diganti, selain itu sebagaimana juga disarankan penelitian diarahkan pada penggunaan anti septik dan zat-zat pengering tradisional misalnya ASI atau kolostrum (Sodikin, 2012).

Salah satu cara yang digunakan untuk perawatan tali pusat adalah aplikasi topikal dari ASI. Menerapkan ASI untuk sisa tali pusat merupakan salah satu praktek perawatan tali pusat budaya yang digunakan di Turki. Kolostrum mengandung komponen pelengkap yang bertindak sebagai agen anti mikroba alami dan juga dilengkapi dengan faktor pelindung yang memberikan kekebalan pasif spesifik dan nonspesifik. ASI dapat mempercepat proses pelepasan tali pusat melalui leukosit plymorphonoklear yang ada pada tali pusat, enzim photolytic dan senyawa imunologi lain yang ada. Studi sebelumnya telah melaporkan bahwa waktu pelepasan tali pusat dengan ASI dan perawatan kering pada bayi lebih pendek dibandingkan dengan aplikasi topikal dari povidone iodine (Allam et al, 2015).

Berdasarkan hasil studi pendahuluan dengan pihak Bidan Praktek Mandiri (BPM) Susilawati Palembang, didapatkan informasi bahwa selama ini cara perawatan tali pusat pada bayi sebagian besar menggunakan kasa kering steril. Selanjutnya jumlah bayi yang lahir di BPM Susilawati Palembang, pada tahun 2014 sebanyak 135 bayi, tahun 2015 sebanyak 119 bayi dan tahun 2016 sebanyak 92 bayi. Sedangkan berdasarkan data dari pihak BPM Ch Mala Palembang, jumlah bayi baru lahir tahun pada tahun 2014 sebanyak 503 orang, tahun 2015 sebanyak 423 orang dan tahun 2016 sebanyak 413 orang

Dari data-data dan uraian tersebut diatas, maka peneliti berminat untuk melakukan penelitian dengan judul "Perbedaan Lamanya Pelepasan Tali Pusat Pada Bayi Ditinjau Dari Perawatan dengan Air Susu Ibu dan Perawatan Kasa Kering di BPM Susilawati dan BPM Ch Mala Palembang Tahun 2017”.

\section{METODE PENELITIAN}

Ruang lingkup penelitian ini ditujukan kepada lamanya pelepasan tali pusat pada bayi ditinjau dari perawatan dengan air susu ibu dan perawatan teknik kering terbuka dengan desain penelitian analitik comparative.

Penelitian dilaksanakan dari tanggal 01 sampai dengan 30 September 2018

Penelitian dilakukan di BPM Susilawati dan BPM Ch Mala Palembang dan berkunjung langsung ke rumah masing-masing responden.

Data primer dalam penelitian ini diperoleh dari lembar observasi yang diisi oleh peneliti sendiri langsung mengamati pelaksanaan 
Jurnal Kebidanan : Jurnal Medical Science Ilmu Kesehatan Akademi Kebidanan Budi Mulia Palembang Volume.8 No.2, Desember 2018

perawatan dengan air susu ibu dan perawatan kasa kering dan menghitung lamanya pelepasan tali pusat pada bayi di Bidan Praktek Mandiri (BPM) Susilawati dan BPM Ch Mala Palembang dan kunjungan ke rumah bayi.

Data sekunder dalam penelitian ini diambil dari pihak Bidan Praktek Mandiri (BPM) Susilawati dan BPM Ch Mala Palembang.

Pengumpulan data dilakukan peneliti langsung dengan cara melakukan observasi dan mencatat semua hasil observasi pada lembar observasi.

Populasi dalam penelitian ini adalah keseluruhan bayi baru lahir di Bidan Praktek Mandiri (BPM) Susilawati dan BPM Ch Mala Palembang dari tanggal 01 sampai dengan 30 September 2018.

Sampel pada penelitian ini berjumlah 20 orang bayi terdiri dari 10 bayi kelompok kontrol (perawatan kasa kering) di BPM Ch Mala Palembang dan 10 bayi kelompok eksperimen (perawatan dengan air susu ibu) di BPM Susilawati Palembang.

Analisis univariat pada penelitian ini dilakukan pada tiap variabel dari hasil penelitian yaitu lama pelepasan tali pusat, perawatan dengan air susu ibu dan perawatan teknik kasa kering.

Pada penelitian ini, analisis bivariat dilakukan dengan terlebih dahulu melakukan uji normalitas data primer menggunakan uji ShapiroWilk dengan ketentuan jika $p$ value $\geq 0,05$ berarti data terdistribusi normal dan jika jika $p$ value < 0,05 berarti data tidak terdistribusi normal.

Selanjutnya untuk uji beda menggunakan uji statistik Independent Samples $t$ Test dengan tingkat kemaknaan alpha 0,05 bila data terdistribusi normal dan Mann Whitney test bila data tidak terdistribusi normal dengan ketentuan jika $p$ value $<0,05$ berarti ada perbedaan dan jika jika $p$ value $\geq$ 0,05 berarti tidak ada perbedaan.

\section{HASIL PENELITIAN}

\section{Analisis Univariat}

Analisis univariat dilakukan untuk mengetahui distribusi frekuensi lamanya pelepasan tali pusat pada bayi dengan air susu ibu dan frekuensi lamanya pelepasan tali pusat pada bayi kasa kering. Hasil penelitian terhadap masingmasing variabel akan diuraikan di bawah ini :

\section{Lamanya Pelepasan Tali Pusat Pada Bayi Dengan Air Susu Ibu}

Pada penelitian ini variabel lamanya pelepasan tali pusat pada bayi dengan air susu ibu dibagi menjadi 3 kategori yaitu cepat, bila tali pusat lepas bayi pada hari $<5$ hari dan normal, bila tali pusat lepas bayi pada hari 5 -7 hari serta lambat, bila tali pusat lepas bayi pada hari $>7$ hari. Untuk lebih jelas terlihat pada Tabel 4.1 dibawah ini.

Tabel 1 Distribusi Frekuensi Responden Berdasarkan Lamanya Pelepasan Tali Pusat Pada Bayi Dengan Air Susu Ibu Di BPM Susilawati Palembang

\begin{tabular}{cccc}
\hline No & $\begin{array}{c}\text { Lamanya } \\
\text { Pelepasan Tali } \\
\text { Pusat Pada } \\
\text { Bayi Dengan } \\
\text { Air Susu Ibu }\end{array}$ & $\begin{array}{c}\text { Frekuensi } \\
\text { (f) }\end{array}$ & $\begin{array}{c}\text { Persentasi } \\
(\%)\end{array}$ \\
\hline 1 & Cepat & 2 & 20 \\
\hline 2 & Normal & 8 & 80 \\
\hline 3 & Lambat & 0 & 0 \\
\hline & Jumlah & 10 & 100 \\
\hline
\end{tabular}

Dari Tabel 1 dapat dilihat bahwa responden lamanya pelepasan tali pusat pada bayi dengan air susu ibu yang cepat berjumlah 2 orang (20\%), yang normal berjumlah 8 orang $(80 \%)$ dan yang lambat berjumlah 0 orang $(0 \%)$.

\section{Lamanya Pelepasan Tali Pusat Pada Bayi Kasa Kering}

Pada penelitian ini variabel lamanya pelepasan tali pusat pada bayi kasa kering dibagi menjadi 3 kategori yaitu cepat, bila tali pusat lepas bayi pada hari $<5$ hari dan normal, bila tali pusat lepas bayi pada hari 5-7 hari serta lambat, bila tali pusat lepas bayi pada hari $>7$ hari. Untuk lebih jelas terlihat pada Tabel 2dibawah ini.

\begin{tabular}{cccc} 
Tabel & $\begin{array}{c}\text { 2Distribusi } \\
\text { Berdasarkan }\end{array}$ & $\begin{array}{c}\text { Frekuensi } \\
\text { Lamanya }\end{array}$ & $\begin{array}{c}\text { Responden } \\
\text { Pelepasan }\end{array}$ \\
BPM Chat Pada Bayi Kasa Kering Di \\
\hline No & $\begin{array}{c}\text { Lamanya } \\
\text { Pelepasan } \\
\text { Tali Pusat } \\
\text { Pada Bayi } \\
\text { Kasa } \\
\text { Kering }\end{array}$ & $\begin{array}{c}\text { Frekuensi } \\
\text { (f) }\end{array}$ & $\begin{array}{c}\text { Persentasi } \\
(\%)\end{array}$ \\
\hline & & \\
\hline 1 & Cepat & 1 & 10 \\
\hline 2 & Normal & 6 & 60 \\
\hline 3 & Lambat & 3 & 30 \\
\hline & Jumlah & 10 & 100 \\
\hline
\end{tabular}

Dari Tabel 2 dapat dilihat bahwa responden lamanya pelepasan tali pusat pada bayi kasa kering yang cepat berjumlah 1 orang (10\%), yang normal 
Jurnal Kebidanan : Jurnal Medical Science Ilmu Kesehatan Akademi Kebidanan Budi Mulia Palembang Volume.8 No.2, Desember 2018

berjumlah 6 orang $(6 \%)$ dan yang lambat berjumlah 3 orang (30\%).

\section{Rata-Rata Lamanya Pelepasan Tali Pusat Pada} Bayi Dengan Air Susu Ibu dan Kasa Kering

Hasil penelitian setelah dilakukan observasi langsung terhadap lamanya pelepasan tali pusat pada bayi dengan air susu ibu sebanyak 10 orang dan kasa kering sebanyak 10 orang, maka dapat diketahui Rata-rata lamanya pelepasan tali pusat pada bayi dengan air susu ibu dan kasa kering sebagaimana terlihat pada tabel 3:

Tabel 3 Rata-Rata Lamanya Pelepasan Tali Pusat Pada Bayi Dengan Air Susu Ibu dan Kasa Kering Di BPM Susilawati dan BPM Ch Mala Palembang

\begin{tabular}{|c|c|c|c|c|c|c|}
\hline $\mathbf{N}$ & Variabel & Mean & Median & $\begin{array}{l}\mathbf{M} \\
\mathbf{i} \\
\mathbf{n}\end{array}$ & $\begin{array}{c}\mathbf{M} \\
\mathbf{a} \\
\mathbf{x}\end{array}$ & SD \\
\hline 1 & $\begin{array}{l}\text { Lamanya } \\
\text { pelepasan } \\
\text { tali pusat } \\
\text { pada bayi } \\
\text { dengan air }\end{array}$ & 5,10 & 5 & 4 & 6 & 0,738 \\
\hline 2 & $\begin{array}{l}\text { susu } \\
\text { Ibu } \\
\text { Lamanya } \\
\text { pelepasan } \\
\text { tali pusat } \\
\text { pada bayi } \\
\text { dengan } \\
\text { kasa } \\
\text { kering }\end{array}$ & 6,60 & 7 & 6 & 9 & 1,578 \\
\hline
\end{tabular}

Berdasarkan tabel 3 diketahui dari 10 orang dengan perawatan tali pusat dengan air susu ibu didapatkan rata-rata lama pelepasan tali pusat adalah 5,10 Sedangkan dari 10 orang dengan perawatan tali pusat dengan kasa kering didapatkan rata-rata lama pelepasan tali pusat adalah 6,60.

\section{Analisis Bivariat}

Pada penelitian ini, sebelum analisis bivariat dilakukan dengan terlebih dahulu melakukan uji normalitas data primer menggunakan uji ShapiroWilk. Adapun hasil uji sebagaimana terlihat pada tabel 4.

Tabel 4 Uji Normalitas Lamanya Pelepasan Tali Pusat Pada Bayi Dengan Air Susu Ibu dan Kasa Kering Di BPM Susilawati dan BPM Ch Mala Palembang

\begin{tabular}{clccc}
\hline No & Variabel & $\begin{array}{c}\text { Shapiro- } \\
\text { Wilk }\end{array}$ & $\boldsymbol{p}$ & Status \\
\hline 1 & Lamanya & 0,911 & 0,067 & Normal \\
& Pelepasan & & & \\
& Tali Pusat & & & \\
& Pada Bayi & & & \\
& Dengan Air & & & \\
& Susu Ibu & & & \\
& dan Kasa & & & \\
& Kering & & & \\
\hline
\end{tabular}

Berdasarkan tabel di atas, diketahui hasil uji normalitas untuk variabel lamanya pelepasan tali pusat pada bayi dengan air susu ibu dan kasa kering mendapatkan nilai Sig 0,067 pada tes Shapiro-Wilk berarti lebih besar $\alpha$ 0,05, maka dinyatakan distribusi data normal.

Selanjutnya analisis bivariat dilakukan untuk melihat perbedaan lamanya pelepasan tali pusat pada bayi ditinjau dari perawatan dengan air susu ibu dan perawatan teknik kasa kering di BPM Susilawati dan BPM Ch Mala Palembang tahun 2017 dilakukan dengan uji Independent Samples $t$ Test karena distribusi data normal. Hasil penelitian dapat dilihat pada tabel 5

Tabel 5 Hasil Analisis Uji dengan Penambahan Informasi Rerata dan Simpang Baku Lama Pelepasan Tali Pusat Pada Bayi Dengan Air Susu Ibu dan Kasa Kering Di BPM Susilawati dan BPM Ch Mala Palembang

\begin{tabular}{lcccc}
\hline & n & $\begin{array}{c}\text { Rerata } \pm \\
\text { s.b }\end{array}$ & $\begin{array}{c}\text { Perbedaan } \\
\text { Rerata } \\
\text { (IK95\% }\end{array}$ & $\begin{array}{c}\boldsymbol{p} \\
\text { value }\end{array}$ \\
\hline $\begin{array}{l}\text { Lamanya } \\
\text { pelepasan }\end{array}$ & 10 & $5,10 \pm$ & $-1,50$ & \\
tali pusat & & 0,738 & $(5,10-6,60)$ & \\
pada bayi & & & & \\
dengan air & & & & \\
susu & & & & $<$ \\
$\begin{array}{l}\text { Ibu } \\
\text { Lamanya }\end{array}$ & 10 & $6,60 \pm$ & & 0,018 \\
pelepasan & & 1,578 & & \\
tali pusat & & & & \\
pada bayi & & & & \\
dengan & & & & \\
kasa & & & & \\
kering & & & \\
\hline
\end{tabular}

Berdasarkan tabel.5 dapat diketahui bahwa rerata lamanya pelepasan tali pusat pada bayi dengan air susu ibu adalah 5,10, sedangkan untuk rerata lamanya pelepasan tali pusat pada bayi kasa kering adalah 6,60 Oleh karena rerata lamanya pelepasan tali pusat pada bayi dengan air susu ibu 
lebih kecil dari pada lamanya pelepasan tali pusat pada bayi dengan kasa kering sehingga dapat dinyatakan bahwa perawatan tali pusat dengan air susu ibu lebih cepat menyebabkan tali pusat pada bayi baru lahir lepas.

Berdasarkan tabel di atas diperoleh nilai signifikansi sebesar lebih kecil dari taraf signifikansi $5 \%(\mathrm{p}$ value $=0,018<0,05)$ maka dapat dinyatakan ada perbedaan lamanya pelepasan tali pusat pada bayi ditinjau dari perawatan dengan air susu ibu dan perawatan teknik kasa kering di BPM Susilawati dan BPM Ch Mala Palembang.

\section{PEMBAHASAN}

\section{Analisis Univariat}

\section{Lamanya Pelepasan Tali Pusat Pada Bayi Dengan Air Susu Ibu}

Berdasarkan hasil penelitian secara univariat terlihat distribusi frekuensi responden dengan responden lamanya pelepasan tali pusat pada bayi dengan air susu ibu yang cepat berjumlah 2 orang (20\%), yang normal berjumlah 8 orang $(80 \%)$ dan yang lambat berjumlah 0 orang $(0 \%)$.

Perawatan tali pusat dengan metode topical ASI adalah perawatan tali pusat yang dibersihkan dan dirawat dengan cara mengoleskan ASI atau kolostrum pada luka dan sekitar luka tali pusat (Pratiwi, 2017).

Dari hasil penelitian dapat dilihat perawatan tali pusat dengan air susu ibu lama pelepasannya lebih baik karena sebagian besar normal dan bahkan ada yang cepat tetapi tidak ada yang lambat.

\section{Lamanya Pelepasan Tali Pusat Pada Bayi Dengan Kasa Kering}

Berdasarkan hasil penelitian secara univariat terlihat distribusi frekuensi responden lamanya pelepasan tali pusat pada bayi kasa kering yang cepat berjumlah 1 orang (10\%), yang normal berjumlah 6 orang (6\%) dan yang lambat berjumlah 3 orang (30\%).

Perawatan tali pusat kasa kering adalah tali pusat dibersihkan dan dirawat serta dibalut kasa steril dengan longgar. Tali pusat dijaga agar bersih dan kering sehingga tidak terjadi infeksi sampai tali pusat kering dan lepas (Putra, 2012).

Dari hasil penelitian dapat dilihat perawatan tali pusat dengan kasa kering lama pelepasan tali pusatnya sebagian besar normal, namun ada yang lambat.

\section{Analisis Bivariat}

Berdasarkan hasil uji normalitas untuk variabel lamanya pelepasan tali pusat pada bayi dengan air susu ibu dan kasa kering mendapatkan nilai Sig 0,067 pada tes Shapiro-Wilk berarti lebih besar $\alpha$ 0,05, maka dinyatakan distribusi data normal.

Selanjutnya hasil penelitian dengan uji Independent Samples $t$ Test diperoleh nilai signifikansi sebesar lebih kecil dari taraf signifikansi $5 \%(\mathrm{p}$ value $=0,018<0,05)$ maka dapat dinyatakan ada perbedaan lamanya pelepasan tali pusat pada bayi ditinjau dari perawatan dengan air susu ibu dan perawatan teknik kasa kering di BPM Susilawati dan BPM Ch Mala Palembang tahun 2017.

Hasil penelitian ini didukung pernyataan Abbaszadeh et al (2016), ASI dapat mempercepat proses pelepasan tali pusat melalui leukosit polimorfonuklear (sel darah putih yang merespons dengan cepat dan menghancurkan antigen asing) yang ada pada tali pusat, enzim proteolisis (enzim penguraian protein) dan imunologi. Air susu memiliki banyak agen imunologi dan anti infeksi dan kolostrum mengandung sejumlah komponen pelengkap yang bertindak sebagai agen antimikroba alami dan juga dilengkapi dengan faktor pelindung yang memberikan kekebalan pasif spesifik dan non spesifik.

Hasil penelitian ini juga didukung pernyataan Aghamohammadi et al (2012), ASI memiliki banyak imunologi dan faktor desinfektan serta merupakan sumber nutrisi terbaik bagi bayi, melindungi bayi baru lahir dari infeksi. Penelitian ini menunjukkan ASI mempercepat pelepasan tali pusat. ASI dapat mempercepat pelepasan melalui leukosit polymorhonuclearyang ada pada tali pusat, protealysis enzim dan senyawa imunologi lainnya.

Hasil penelitian ini sejalan dengan penelitian yang dilakukan oleh Jayanti dkk (2015), dengan judul "Perbedaan Lama Pelepasan Tali Pusat Antara Perawatan Kasa Topikal ASI Dan Kasa Steril Di Wilayah Kerja BPM Istiqomah Kabupaten Banjarnegara Tahun 2015”. Hasil penelitian diperoleh ada perbedaan lama pelepasan tali pusat antara perawatan kasa topical ASI dibandingkan dengan kasa steril $(\mathrm{p}=0,027)$.

Hasil penelitian ini juga sejalan dengan penelitian yang dilakukan oleh Subiastutik (2012), dengan judul "Efektifitas Pemberian Topikal ASI Dibanding Perawatan Kering Terhadap Kecepatan Waktu Lepas Tali Pusat Di Puskesmas Sumbersari Jember". Menunjukkan hasil analisis bivariat, terdapat perbedaan nilai rata-rata lama waktu lepas tali pusat yang dilakukan perawatan dengan topikal ASI dan perawatan kering dengan nilai $p<0,000$, sehingga terdapat perbedaan yang signifikan secara statistik antara perawatan tali pusat dengan topikal 
ASI terhadap lama waktu lepas tali pusat, yaitu waktu rata-rata lepas pada tali pusat dengan perawatan topikal ASI lebih singkat dibanding perawatan kering.

Hasil penelitian ini juga sejalan dengan penelitian yang dilakukan oleh Sofiana dkk (2011), dengan judul "Efektifitas Metode Kolostrum Dan Metode Kasa Kering Terhadap Waktu Pelepasan Tali Pusat di BPS Ny. Endang Purwaningsih Dan BPS Ny. Istiqomah Kecamatan Rakit Kabupaten Banjarnegara". Menunjukkan Hasil analisa nilai $\mathrm{p}$ $=0,006$. Nilai ini lebih kecil dibandingkan dengan nilai $\alpha$ (alpha) $=0,05$, sehingga dapat disimpulkan bahwa Ho ditolak, artinya ada perbedaan waktu pelepasan tali pusat antara perawatan tali pusat dengan menggunakan metode kolostrum dibandingkan dengan menggunakan metode kasa kering, dimana perawatan menggunakan metode kolostrum lebih cepat 34,71 jam dibandingkan dengan menggunakan metode kasa kering.

Dari hasil penelitian ini dapat dilihat bahwa ada perbedaan lamanya pelepasan tali pusat pada bayi ditinjau dari perawatan dengan air susu ibu dan perawatan teknik kasa kering. Dimana waktu pelepasan tali pusat yang menggunakan Air susu ibu (ASI) lebih cepat lepas yaitu yang tercepat 4 hari dan terlambat 6 hari, sehingga bila dihitung secara rata-rata sekitar 5 hari, sedangkan dengan lama waktu perawatan tali pusat yang menggunakan kasa kering yaitu yang tercapat 4 hari dan yang terlambat 9 hari, sehingga bila dihitung secara rata-rata sekitar 6 hari. Hal ini dapat terjadi karena air susu ibu mengandung komponen terlengkap yang bertindak sebagai agen anti mikroba alami dan juga di lengkapi dengan faktor pelindung yang memberikan kekebalan pasif spesifik dan non spesifik, sehingga dapat mempercepat proses pelepasan tali pusat melalui leukosit plymorphonoklear yang ada pada tali pusat, enzim photolitic dan senyawa imonologi lain yang ada.

\section{KESIMPULAN}

1. Distribusi frekuensi responden dengan responden lamanya pelepasan tali pusat pada bayi dengan air susu ibu yang cepat berjumlah 2 orang $(20 \%)$, yang normal berjumlah 8 orang $(80 \%)$ dan yang lambat berjumlah 0 orang (0\%). Responden lamanya pelepasan tali pusat pada bayi kasa kering yang cepat berjumlah 1 orang $(10 \%)$, yang normal berjumlah 6 orang (6\%) dan yang lambat berjumlah 3 orang $(30 \%)$.

2. Uji normalitas untuk variabel lamanya pelepasan tali pusat pada bayi dengan air susu ibu dan kasa kering mendapatkan nilai Sig 0,067 pada tes Shapiro-Wilk berarti lebih besar $\alpha$ 0,05, maka dinyatakan distribusi data normal.

3. Hasil uji Independent Samples t Test diperoleh nilai signifikansi sebesar lebih kecil dari taraf signifikansi $5 \%(\mathrm{p}$ value $=0,018<0,05)$ maka dapat dinyatakan ada perbedaan lamanya pelepasan tali pusat pada bayi ditinjau dari perawatan dengan air susu ibu dan perawatan teknik kasa kering di BPM Susilawati dan BPM Ch Mala Palembang.

\section{SARAN}

\section{Bagi BPM Petugas Kesehatan}

Agar dapat mengembangkan dan mensosialisasikan perawatan tali pusat dengan air susu ibu yang dapat menyebabkan tali pusat lebih cepat lepas, karena air susu ibu memiliki banyak agen imunologi dan anti infeksi, sehingga dapat mencegah terjadi infeksi pada tali pusat bayi.

\section{Bagi Akademi Kebidanan Budi Mulia Palembang}

Agar pihak institusi pendidikan dapat menjadi penelitian ini sebagai bahan acuan dan merupakan sumber informasi yang bermanfaat untuk pengetahuan mahasiswa khususnya perawatan tali pusat dengan air susu ibu yang dapat mempercepat waktu pelepasan tali pusat, yang sebenar sudah digunakan sejak lama namun sekarang kurang dikenal.

\section{Bagi Peneliti Selanjutnya}

Agar dapat menjadikan hasil penelitian ini sebagai referensi dalam meneruskan penelitian ini dengan metode penelitian yang berbeda seperti menggunakan metode case control agar penelitian ini mengalami perkembangan dan dapat memberikan hasil penelitian yang lebih baik.

\section{DAFTAR PUSTAKA}

Abbaszadeh, Fatemeh, Zanab Hajizadeh and Mohammad Jahangiri. 2016. Comparing the impact of topical application of human milk and chlorhexidine on cord separation time in newborns. Pak J Med Sci. 2016;32(1):239-243.

Allam, Nehal A, Wafa A. AL Megrin and Amal M. Talat. 2015. The Effect of Topical Application of Mother Milk on Separation of Umbilical Cord for Newborn Babies. American Journal of Nursing Science Volume 4, Issue 5, October 2015, Pages:288-296. 
Jurnal Kebidanan : Jurnal Medical Science Ilmu Kesehatan Akademi Kebidanan Budi Mulia Palembang Volume.8 No.2, Desember 2018

Aghamohammadi, Azar, Mandana Zafari and Leila Moslemi. 2012. Comparing the Effect of Topical Application of Human Milk and Dry Cord Care on Umbilical Cord Separation Time in Healthy Newborn Infants. Iranian Journal of Pediatrics \& Tehran University of Medical Sciences 2012 Jun; 22(2): 158-162.

Azwar, Saifuddin. 2014. Metode Penelitian. Yogyakarta: Pustaka Pelajar.

Dahlan, Sopiyudin M. 2013. Statistik Untuk Kedokteran Dan Kesehatan. Jakarta: Salemba Medika.

Dinkes Kota Palembang. 2015. Angka Kematian Ibu dan Angka Kematian Bayi di Kota Palembang Tahun 2013, 2014 dan 2015.

Dinkes Provinsi Sumsel. 2015. Angka Kematian Ibu dan Angka Kematian Bayi di Provinsi Sumatera Selatan Tahun 2013, 2014 dan 2015.

Djami, Moudy E.U. 2013. Isu Terkini dan Evidence Based dalam Praktik Kebidanan, online http://www.akbidbinahusada.ac.id/.

Hidayat, A Aziz Alimul. 2014. Metode Penelitian Kebidanan dan Teknik Analisis Data. Jakarta : Salemba Medika.

Jayanti, Novi, Musruroh dan Puji Pranowowati. 2015. Perbedaan Lama Pelepasan Tali Pusat Antara Perawatan Kasa Topikal ASI Dan Kasa Steril Di Wilayah Kerja BPM Istiqomah Kabupaten Banjarnegara Tahun 2015. Jurnal Ngudi Waluyo Ungaran.

Kompas. 2016. Turunkan Angka Kematian Bayi, Perempuan Harus Punya Pengetahuan Kehamilan, online http://health.kompas.com.

Irawan, Kusuma Nungki. 2011. Menumpas Penyakit Dengan Darah Tali Pusat. Jakarta: Berlian Media.

Marmi. 2012. Intranatal Care Asuhan Kebidanan Pada Penelitian. Yogyakarta: Pustaka Pelajar.

Maryunani, Anik dan Nurhayati. 2008. Buku Saku Asuhan Bayi Baru Lahir Normal (Asuhan Neonatal). Jakarta: Trans Info Media.

Notoatmodjo, Soekidjo. 2012. Metodologi Penelitian Kesehatan. Jakarta : Rineka Cipta.
Nurasiah, Ani Rukmawati dan Dewi Laelatul Badriah. 2012. Asuhan Persalinan Normal Bagi Bidan. Yogyakarta: Refika Aditama.

Pratiwi, Erlina Hadi Nur. 2017. Pelepasan Tali Pusat Dengan Perawatan Topikal ASI, online http://www.academia.edu.

Putra, Rizema Sitatava. 2012. Asuhan Neonatus Bayi dan Balita untuk Keperawatan dan Kebidanan. Jogjakarta: D-Medika.

Rohani. 2016. TOPIK 1 Konsep dasar evidence based midwiferyberspektif gender dan HAM dalam asuhan kebidanan, online http://rohanihasanuddin. blogspot.co.id/2016/.

Saifuddin, Abdul Bari. 2014. Ilmu Kebidanan Sarwono Prawirohardjo. Jakarta: Bina Pustaka Sarwono Prawirohardjo.

Saleha, Sitti. 2009. Asuhan Kebidanan Pada Masa Nifas. Jakarta: Salemba Medika.

Sodikin. 2012. Buku Saku Perawatan Tali Pusat. Jakarta: EGC.

Sofiana, Ika dan Ely Eko Agustina. 2011. Efektifitas Metode Kolostrum Dan Metode Kasa Kering Terhadap Waktu Pelepasan Tali Pusat di BPS Ny. Endang Purwaningsih Dan BPS Ny. Istiqomah Kecamatan Rakit Kabupaten Banjarnegara. Jurnal Akademi Kebidanan YLPP Purwokerto.

Subiastutik, Eni. 2012. Efektifitas Pemberian Topikal ASI Dibanding Perawatan Kering Terhadap Kecepatan Waktu Lepas Tali Pusat Di Puskesmas Sumbersari Jember. Jurnal IKESMA Volume 8 Nomor 1 Maret 2012.

Sugiyono. 2014. Metode Penelitian Kuantitatif, Kualitatif Dan $R \& D$. Bandung: Alfabeta.

Sumaryani, Sri. 2009. Pelepasan Tali Pusat dan Omphalithis Kajian terhadap Perawatan dengan Air Susu Ibu, Alkohol 70\% dan Teknik Kering Terbuka. Jurnal Mutiara Medika Vol.9 No.1:42-49, Januari 2009.

Tempo. 2014. UNICEF: Angka Kematian Anak di Dunia Menurun, online http://tempo.com. 
Jurnal Kebidanan : Jurnal Medical Science Ilmu Kesehatan Akademi Kebidanan Budi Mulia Palembang Volume.8 No.2, Desember 2018

Wiknjosastro, Gulardi H. 2008. Asuhan

Persalinan Normal Asuhan Esensial. Jakarta: JNPK-KR Depkes RI.

Yefri, Riza, Mayetti dan Rizanda Machmud. 2014.

Kolonisasi Kuman dan Kejadian Omfalitis

Pada Tiga Regimen Perawatan Tali Pusat

Pada Bayi Baru Lahir. Sari Pediatri, Vol.

11, No. 5, Februari 2014. 
